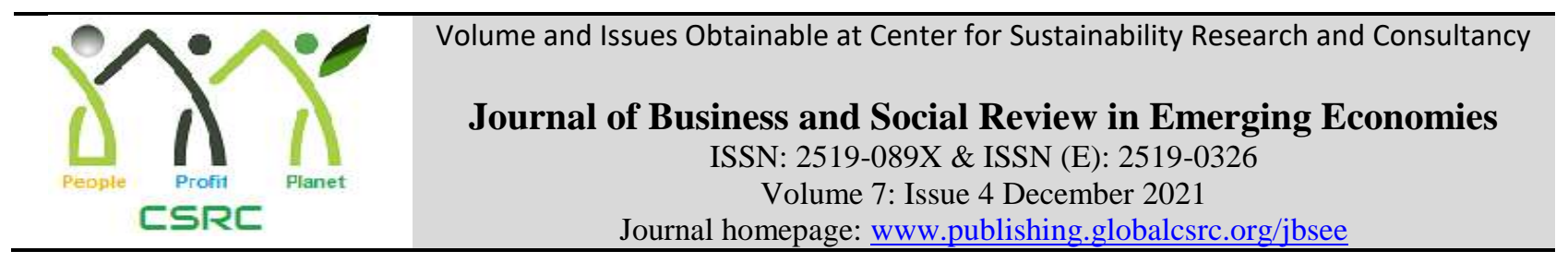

\title{
Factors Affecting the Acceptability of Islamic Micro-Finance in Emerging Economy
}

Muhammad Akbar Ali Ansari, Department of Commerce, The Islamia University of Bahawalpur, Pakistan

*Ali Junaid Khan, Institute of Business Management and Administrative Sciences, The Islamia University of Bahawalpur, Pakistan

Nadia Hanif, Department of Economics and Business Administration, Division of Administrative and Management Science, University of Education, Lahore, Pakistan

Tanveer Ahmed, Department of Environmental Management, National College of Business Administration \& Economics, Lahore, Pakistan

*Corresponding author's email: Junaaidkhan@yahoo.com

\begin{tabular}{l}
\hline ARTICLE DETAILS \\
\hline History \\
Revised format: Nov 2021 \\
Available Online: Dec 2021
\end{tabular}

Keywords

Islamic-microfinance,

Emerging economy,

Shariah-based, Pakistan

JEL Classification

G20, G21

\section{ABSTRACT}

Purpose: Microfinance institutions impose a very high interest rate only to enhance the wealth of owner of the institution and stockholders. However, Islamic microfinance is the opposite of traditional microfinance; it is a form of interest-free financing dedicated to societal well-being. The research's primary objectives are to identify public knowledge of Shariah-based microfinance and ascertain the factors that contribute to the acceptance of Islamic microfinance in Pakistan. Design/Methodology/Approach: This study investigated the significance of shariah-based microfinance in Pakistan, which is based on the Islamic financial system, and used a quantitative descriptive technique to estimate the factors.

Findings: There are several factors that give to the acceptability of Islamic banking. The most important variables are: cost-benefit analysis, business support, product and service quality, religious obligation, awareness and knowledge, trust and reputation. After an examination of all the acceptability factors, it was found that each factor has an effect on the acceptability of Islamic microfinance in Pakistan.

Implications: The study has various implications for policymakers wishing to promote Islamic microfinance at the levels of national and international.

(C) 2021 The authors, under a Creative Commons Attribution

NonCommercial 4.0

Recommended citation: Ansari, M. A. A., Khan, A. J., Hanif, N. and Ahmed, T. (2021). Factors Affecting the Acceptability of Islamic Micro-Finance in Emerging Economy. Journal of Business and Social Review in Emerging Economies, 7 (4), 1011-1022 


\section{Introduction}

\section{Background of the Research}

Microfinance (MF) is the provision of modest loans to the poor masses (particularly those who cannot access financial services from conventional banks) through MF programs that are tailored to meet the individual needs of the people (Khan, 2008). Micro-finance is defined by Abedelhamid (1991) as "the transfer of money, loans, and insurance to the underprivileged as well as small business owners." "The method of offering a range of financial services to the impoverished based on market-driven and commercial techniques" is how Christen (1997) defines the word "microfinance." Non-financial services can help microfinance move its attention away from lending to low-income people and toward fulfilling the dual goals of social outreach and financial sustainability (Bos and Millone 2015, Zamore et al. 2019). Researches have shown that these initiatives have significantly improved women's security, independence, status, and self-assurance (Khan \& Rahaman, 2007). Microfinance is a fundamental part of economic growth and poverty eradication. As new business ventures, self-employment, and self-help organizations are fostered via the use of microfinance, rural employment is expected to grow. This, in turn, will reduce emigration and expedite rural development (Gupta, 2014). Microfinance may be a new way to stimulate growth in the developing world's most impoverished regions (Khavul, 2010; Muhammad, 2020).

Yusuf (2006) emphasizes the Muslim Ummah's opposition to Western culture. It is their belief that adhering strictly to Islamic Shariah law is the only way to solve the current economic crisis. Islamic finance, according to Frasca (2008), may be a viable haven for depositors who have been harmed by the global financial crisis. It protects them against the traditional financial system's expected excess. The majority of people do not appear to use conventional microfinance programs since they are based on riba (interest), which Islam prohibits (Goud, 2007). As a means of providing financial assistance to small firms run by low-income entrepreneurs, Islamic microfinance (IMF) is frequently discussed (Smolo, 2007). Some small business owners might benefit from Islamic banking, which offers interest-free loans with no collateral and risk sharing (Rahul and Sapcanin, 1998). Islamic banking describes not just banking that does not charge interest, but also how ethics and finance may be integrated as a concept to serve and lead society for the greater good (Babar, 2019). According to Obaidullah, (2008). The poor seek Islamic microfinance products, such as micro savings, micro loans, micro remittances, micro insurance, and micro equity, to help them. Masses of people invest in profit-making methods that allow them to give services to the underprivileged within the Islamic financial framework of thought. Slight adjustments might make it suitable for microfinance (Obaidullah, 2008).

\section{Statement of the Problem}

The study will investigate the factors that make Islamic microfinance acceptable to Pakistan's small investors. Micro-finance has been the subject of several research studies in Pakistan, Islamic microfinance strives to end the cycle of poverty and lift the needy out of poverty. Furthermore, the study by Ashrafi (2017) indicated that traditional microfinance has failed to break the poverty cycle in this country and little is known about its impact on the country's economy so far. Saad (2012). Islamic microfinance products are in great demand, and if banks and microfinance institutions launch them, then poor and needy individuals will be able to obtain loans or credit to meet their requirements (Saad, 2012). Microcredit is a form of interest-free lending that is used to benefit society as a whole. Through Islamic micro-financing schemes, more ethical and economically beneficial conduct is encouraged (Rahman, 2010).

\section{Objectives of the Research}

These are main objectives that are developed for this study: 
1. To investigate the understanding regarding Islamic micro-finance among the people in Pakistan.

2. To investigate the factors that affecting the acceptance of Islamic micro-finance in Pakistan.

\section{Literature Review}

Numerous research studies have been conducted worldwide on micro-finance. So little research has been conducted so far on Islamic microfinance and its acceptability in various countries, most notably Pakistan. This research will contribute to the current body of knowledge by providing a new research direction..

\section{Micro Financing}

Microfinance was introduced for the first time in 1976 in Bangladesh. At the time, the concept of microfinance had grown globally, particularly in third-world countries ("Latin America, Africa and Asia"), as well as in better-off economies like the North American countries and European countries. (Abdelkader \& Salem). Otero (2006), tiny microcredit activities began in the mid-17th century. The majority of microfinance institutions operate in poor nations. (Kaburi et al., 2013) argue that microfinance's primary objective is poverty reduction. Poverty alleviation in global expansion is a significant role of microfinance (Santandreu et al., 2020 and Wright et al., 2019). According to Frasca (2008), microfinance originated in the 1970s in Bangladesh as an experimental programs in which modest loans were made to a group of underprivileged women by a state-funded non-governmental organization to engage in productive activities. Microfinance has become increasingly recognized as a key component of poverty reduction strategies over the last few decades. This recurrence of misfortunes is much more pronounced for poor individuals, as the majority of them are regularly victims of natural disasters, theft, and fire (Patel, 2004; Ahmad, 2007; Obaidullah, 2008).

The term "microfinance" has been defined by a variety of scholars. According to Otero (1999), microfinance defines as "offering of financial services to those people who have low income and highly impoverished self-employed persons". Schreiner and Colombet (2001), is "an effort to expand underprivileged households' access to small deposits and small loans." Microfinance, as defined by Ledgerwood (1999), is financial services offered to low-income persons, typically in the form of loans and savings.

Microfinance, as defined by Brandsma and Burjorjee (2004), contains the following characteristics:

- With a particular emphasis on poor business individual who do not have access to commercial banks, it facilitates access to borrowed short-term, small loans through the use of substitute collateral.

- It also provides voluntary savings services to allow for more manageable deposits and more convenient access to funds. According to the Asian Development Bank (2000) and La Torre and Gianfranco (2001), government regulation of microfinance may be divided into three types (2006). Islamic finance is a type of financing that uses Islamic principles.

Islamic Financing is a term that refers to a financial system that follows Islamic (sharia) based laws. Islamic banking is founded on Islamic basic principles of economic and social justice, as well as equitable distribution of wealth.

The fundamental rules and concepts governing Islamic finance trace all the way back to the early seventh century, and include the following:

1. Prohibition/ban on Riba (interest).

2. Sharing of risk.

3. Contract's sanctity.

4. Activities according to Shariah. 


\section{Islamic Microfinance}

El-Kommi \& Croson (2012). Islamic microfinance is derived from Islamic banking. Nonetheless, sizable sections of the underprivileged are Muslims, and as a result, They are unable to benefit from traditional microfinance contracts that demand of interest payments As "Dr. Abbas Mirakhor, Executive Director of the International Monetary Fund", noted in Chaudhri (2006), "a critical function of Islamic finance that is frequently overlooked is its capacity to serve as a economical and financial empowerment, converting idle fund into income generating recourses in order to economically empower the poor people." Muftis Muhammad Taqi Usmani says that Islamic Shari'ah bans the practice of Riba for all financial transactions, and hence Muslims have been seeking for a long time to define their way of life in accordance with Islamic teachings. Islamic Microfinance is a way to provide loans to the underprivileged without relying on the concept of interest payments. It is necessary to alter microfinance more fundamentally in order to accommodate Islamic value financing arrangements. It is important to remember that microfinance initiatives are founded on a collective sharing of risk and individual certainty, and that maintaining trust and honesty is tied to future money availability.

Islamic micro-finance is a solution for Muslim people who are unable to access traditional financial services. It was decided that a descriptive analysis would be used by the author. The researcher used a semi-structured interview and a questionnaire to examine the economic effects of Islamic microfinance on the client. Financial demands can be met at a low cost using Islamic microfinance programs. A merger of Islamic banking and microfinance was being considered as a possible move. Dhumale and Sapcanin (1999). These three Islamic financial tools - murabaha, mudaraba, and the three types of musharaka-were taken into consideration in the hopes of creating an effective microfinance scheme. An Islamic financial system may give microfinance to a large number of small business individual as well as poor people, who might not be consider It if conventional business loans (Interest based) were available. Additional practices and experimentation in the sector should result in increased knowledge and a greater acceptance of Islamic banking efficient loan delivery procedure (Muhammad Ramzan, 1996).

Table 1: Conceptualization of Framework from Existing Literature

\begin{tabular}{|c|c|c|}
\hline S. \# & Variables & References \\
\hline 1 & Cost Benefits" & $\begin{array}{l}\text { "(Al-Ajmi et al. 2009), (Gait and Worthington, 2008); (Hamid and } \\
\text { Masood, 2011)" }\end{array}$ \\
\hline 2 & Business Support & "(Gait and Worthington, 2009), (Yusoff and Yacob, 2010)" \\
\hline 3 & $\begin{array}{l}\text { Quality Products and } \\
\text { services }\end{array}$ & "Hedayatnia \& Eshghi (2011), Haque et al., (2009)" \\
\hline 4 & Religion obligation & "(Amin et al, 2011), (Butt et al, 2011)" \\
\hline 5 & $\begin{array}{l}\text { Awareness and } \\
\text { knowledge }\end{array}$ & $\begin{array}{l}\text { "(Writz and Matilla, 2003), Haron (1994), (Gerard, 1997), Kamal et al., } \\
\text { 1999)" }\end{array}$ \\
\hline 6 & Trust & $\begin{array}{l}\text { "(Rousseau et al., 1998), (Sirdeshmukh et al., 2002), (Lewis and Weigert, } \\
\text { 1985) (Mayer et al., 1995), (Pavlou, 2003), Johnson, 2007).(Johnson et al., } \\
\text { 2008), (Yap et al., 2010; Yoon, 2002,), (Suh andHan, 2003, Gholami et al., } \\
\text { 2010, George, 2002, Sohail and Shanmugham, 2003, Liu and Wu,2007, } \\
\text { Gefen, 2000)". }\end{array}$ \\
\hline 7 & Bank Reputation & $\begin{array}{l}\text { "Almossawi (2001), Aregbeyen (2011), Gerrard and Cunningham (2001), } \\
\text { Cicic et al. (2004)". }\end{array}$ \\
\hline
\end{tabular}




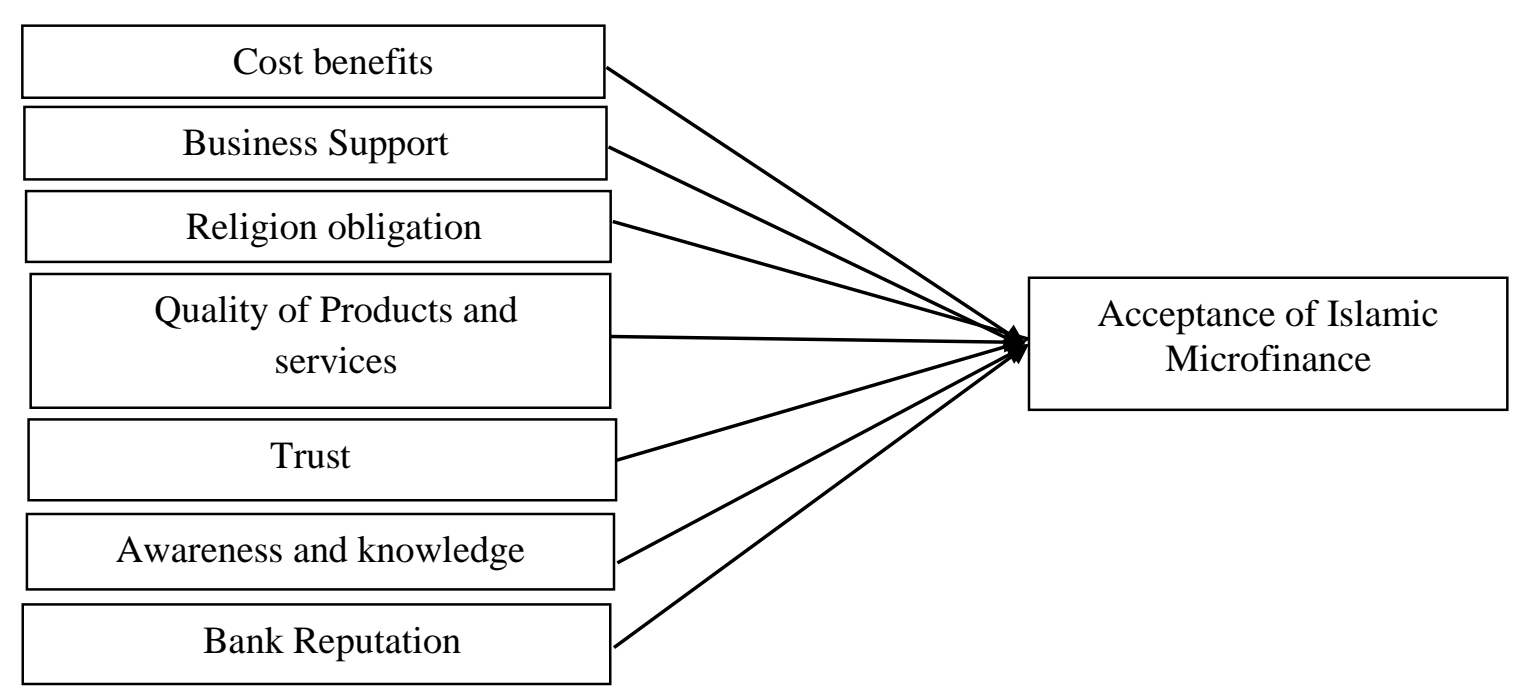

Fig 1: Conceptual Framework

\section{Research Methodology}

The quantitative approach of research analysis is the most effective strategy for determining the final results and accepting or rejecting a hypothesis (Shuttleworth, 2008). With the objectives and scope of the research in mind, as well as the nature of the population and sample strategy, it is concluded that the quantitative approach is the most appropriate methodology for achieving the objectives. (1993, Burns and Grove)

According to all participants of the population must share the study's specific characteristics (Polit and Hungler, 1999). Due to the fact that the study is investigating the acceptance of Islamic microfinance in Pakistan, therefore, the population of the study should be the clients of micro finance institution in Pakistan. But unfortunately in Pakistan none of the bank (Islamic or Conventional) is offering the Islamic micro financing facilities to its clients. Therefore, keeping in view this issue, current study considers the clients of Islamic banks, Islamic branches of commercial banks and conventional micro financing institutions of Bahawalpur region as population as shown in the table given below.

Most of the studies in the banking sector are based on secondary data, whereas this study is based on primary data. As a result, a sample size of 300 would be used. Comrey and Lee (1992) defined inferential statistics as a sample in a series. The sampling strategy used is important because it has an effect on the outcomes (Miles \& Huberman, 1994). 300 questionnaires would be distributed evenly among the banking sector. This research will propose the use of stratified random sampling to provide enough representation from each sector. The questionnaire was adapted from one provided by (Tara etal, 2014). Keeping the sampling frame in mind, a total of 300 questionnaires were dispersed evenly across the banking industry. 262 replies were collected following repeated conversations and inquiries.

\section{Results and Discussions}

In the present study, it has analyzed the results of 262 questionnaires.

Table 1:Demographic descriptive analysis

\begin{tabular}{lccccccc}
\hline & N & Range & Minimum & Maximum & Mean & Std. Deviation & Variance \\
\hline "Age" & & & & & & & \\
\hline "Gender" & 262 & 4 & 1 & 5 & 2.96 & 1.105 & 1.220 \\
"Income" & 262 & 1 & 1 & 2 & 1.25 & 0.433 & 0.187 \\
\hline
\end{tabular}




\begin{tabular}{llllllll}
\hline "Qualification" & 262 & 4 & 1 & 5 & 3.82 & 1.271 & 1.617 \\
"Status" & 262 & 2 & 2 & 4 & 3.59 & 0.611 & 0.373 \\
"Valid N"(list wise) & 262 & 2 & 1 & 3 & 2.91 & 0.625 & 0.390 \\
& 262 & & & & & & \\
\hline
\end{tabular}

\section{Reliability Measurement}

To measure the research's internal reliability and the questionnaire's clarity and readability. As seen in Table 2, the reliability value is 0.87 ; value of Cronbach's alpha is better than " 0.7 " is acknowledged to be acceptabe consistent for items evaluating a particular thought or idea (Nunnally and Bernstein, 1994; Nunnally, 1978). Endorsed the idea and established that only items with a Cronbach's Alpha value greater than 0.870 should be deemed consistent (Bernstein and Sekaran, 2003).

Table 2:Reliability Statistics

\begin{tabular}{cc}
\hline Cronbach's Alpha & N of Items \\
\hline .870 & 8 \\
\hline
\end{tabular}

Table 3: Regression Analysis

\begin{tabular}{|c|c|c|c|}
\hline Hypotheses & Beta & t-value & Sig. \\
\hline $\begin{array}{l}\text { H1: Acceptance of Islamic micro-finance has been significant affect by cost } \\
\text { benefit. }\end{array}$ & .283 & 4.764 & .000 \\
\hline $\begin{array}{l}\text { H2: Acceptance of Islamic micro-finance has been significant affect by } \\
\text { business support. }\end{array}$ & .369 & 6.407 & .000 \\
\hline $\begin{array}{l}\text { H3: Acceptance of Islamic micro-finance has been significant affect by quality } \\
\text { of products and services. }\end{array}$ & .315 & 5.355 & .000 \\
\hline $\begin{array}{l}\text { H4: Acceptance of Islamic micro-finance has been significant affect by } \\
\text { religious obligation. }\end{array}$ & .439 & 7.889 & .000 \\
\hline $\begin{array}{l}\text { H5: Acceptance of Islamic micro-finance has been significant affect by } \\
\text { awareness and knowledge. }\end{array}$ & .359 & 6.196 & .000 \\
\hline H6: Acceptance of Islamic micro-finance has been significant affect by trust. & .383 & 6.691 & .000 \\
\hline $\begin{array}{l}\text { H7: Acceptance of Islamic micro-finance has been significant affect by bank } \\
\text { reputation. }\end{array}$ & .300 & 5.070 & .000 \\
\hline
\end{tabular}

According to Table \# 6, The factors for Islamic-microfinance have a significant and positive impact on acceptability in Pakistan, and the values of R-square shows that in the comparison, this model is fit in the best manner.

Table 5: Model Summary

\begin{tabular}{|c|c|c|c|c|c|c|c|c|c|c|}
\hline \multirow[b]{2}{*}{$\begin{array}{l}\text { Mode } \\
1\end{array}$} & & \multicolumn{9}{|c|}{ Change Statistics } \\
\hline & $\mathrm{R}$ & R Square & $\begin{array}{l}\text { Adjusted } \\
\text { Square }\end{array}$ & $\begin{array}{l}\text { R Std. Error of } \\
\text { the Estimate }\end{array}$ & $\begin{array}{l}\mathrm{R} \text { Square } \\
\text { Change }\end{array}$ & F Change & df1 & df2 & $\begin{array}{l}\text { Sig. } \\
\text { Change }\end{array}$ & $\mathrm{F}$ \\
\hline 1 & $.489^{a}$ & .239 & .218 & .47489 & .239 & 11.411 & 7 & 254 & .000 & \\
\hline
\end{tabular}

a. Predictors: (Constant), R, QPS, BS, T, AK, CB, RO 
Table 6:ANOVA ${ }^{b}$

\begin{tabular}{lllllll}
\hline Model & & Sum of Squares & Df & Mean Square & F & Sig. \\
\hline 1 & Regression & 18.013 & 7 & 2.573 & 11.411 & $.000^{\mathrm{a}}$ \\
& Residual & 57.282 & 254 & .226 & & \\
& Total & 75.295 & 261 & & & \\
\hline
\end{tabular}

a. Predictors: (Constant), R, QPS, BS, T, AK, CB, RO

b. Dependent Variable: AC

H1: Acceptance of Islamic micro-finance has been significant affect by cost benefit.

The research confirm that cost benefits have an effect on the acceptance of Islamic micro-finance, the "Hypothesis 1" has accepted. Because the coefficient is" 0.283 " and the t-value was "4.764", the results strongly supported the hypothesis. This supported the findings of (Al-Ajmi et al, 2009; Gait and Worthington, 2008).

H2: Acceptance of Islamic micro-finance has been significant affect by business support. This research confirms that business support has an effect on the acceptance of Islamic microfinance, hence accepting the "Hypothesis 2 ".. Because the coefficient was " 0.369 " and the $t-$ value was "6.407", these results are in the support of the hypothesis. This was also supported by (Yusoff and Yacob, 2010).

\section{H3: Acceptance of Islamic micro-finance has been significant affect by quality of products and services.}

Hypothesis 3 investigated the effect of product and service quality on the acceptance of Islamic microfinance. Because the coefficient was " 0.315 " and this t-value was "5.355", these results are highly in the support of the hypothesis. This confirms the findings of (Haque et al, 2009).

H4: Acceptance of Islamic micro-finance has been significant affect by religious obligation.

"Hypothesis 4" investigated the effect of religious requirements on the acceptance of Islamic microfinance. Because coefficient was " 0.439 " and t-value was " 7.889 ", these results are highly in the support of the hypothesis. There is a fact that there is a positive result that is smaller than one that indicates the religious obligations have an effect on the acceptance of Islamic microfinance and are strongly supported by the other variables. This confirms the findings of (Amin et al, 2011).

\section{H5: Acceptance of Islamic micro-finance has been significant affect by awareness and knowledge.}

The effect of awareness and knowledge on the acceptance of Islamic microfinance was studied in "Hypothesis 5". The fact that the coefficient was " 0.359 " and the t-value was "6.196" strongly supported the hypothesis. This confirms the findings of (Kamal et al, 1999; Writz and Matilla, 2003).

H6: Acceptance of Islamic micro-finance has been significant affect by trust.

The effect of trust on the acceptability of Islamic microfinance was studied in "Hypothesis 6". The fact that the coefficient value of the factor is " 0.383 " and t-value is " 6.691 ", which indicates about the data that is highly support the hypothesis. This conclusion is corroborated by the finding of (Gholami et al, 2010).

H7: Acceptance of Islamic micro-finance has been significant affect by bank reputation.

The effect of a bank's reputation on the acceptance of Islamic microfinance was studied in "Hypothesis 7". The fact that the coefficient was " 0.300 " and the t-value was "5.070" strongly 
supported the hypothesis. This confirms the findings of (Almossawi, 2001).

\section{Conclusion}

Microfinance (MF) is the provision of small loans to the poor masses through MF programmes that are tailored to meet the individual requirements of the people (Khan, 2008). These two terms, microfinance and microcredit, are often used interchangeably. Both, however, differ somewhat. "The method of offering a range of financial services to the impoverished based on market-driven and commercial techniques," is how Christen (1997) defines the word "microfinance." Islamic microfinance (IMF) is frequently discussed as a means of providing financial assistance to small company owners in need, whether they are just starting out or looking to expand their operations (Smolo, 2007). Some small business owners might benefit from Islamic banking, which uses risk sharing and interest-free financing (Rahul and Sapcanin, 1998). Despite the fact that microfinance has been a huge success, the transaction costs are quite high. In spite of its many success/acceptability factors, traditional micro-finance has certain non-acceptability elements such as high cost, interest rate and religion component.

Islamic microfinance schemes are in high demand in the microfinance industry, as evidenced by several studies. If banks and microfinance institutions implement Islamic microfinance schemes, the poor and credit-insecure will be able to obtain loans and credit to meet their requirements (Saad,2012). In order to relieve poverty, Islamic micro-financing programmes encourage more ethical and economically beneficial conduct (Rahman, 2010). In contrast to those who support conventional microfinance, proponents of Islamic microfinance want to see the advancement of Islamic society rather than the promotion of principles that could be in conflict with shariah (Wilson, 2007). Islamic finance is a relatively new idea in Pakistan and has necessitated much effort. Thus yet, very little study has been conducted to investigate the phenomena. As a result, this research will be utilized to determine the characteristics that contribute to the acceptability of Islamic microfinance among small investors in Pakistan.

\section{Theoretical Implications}

In the previous, researchers have investigated at the factors that impact acceptance or adoption; however the majority of the studies are focused on Islamic finance or Islamic banking "(Gait and Worthington, 2008; Al-Ajmi et al., 2009; Haque et al., 2009; Amin et al., 2011; Kamal et al., 1999; Almossawi, 2001)". An significant research gap was addressed in Pakistani Islamic microfinance as a result of this study. Previous research has focused on the factors that influence the acceptance or implementation of Islamic finance or Islamic banking.

\section{Managerial Implications}

The findings of this study expand and enrich the scope of past research in various ways. Banks needs be more aggressive and intensive in order to educate the peoples about Islamic microfinancing. This means that in order to reach potential customers, Islamic microfinance has to run informed and successful advertising efforts. Islamic microfinance products should be advertised via electronic and print media, the internet, and the outdoors. The state bank of Pakistan should also provide framework and policy guidelines for the expansion and development of Islamic microfinance institutions in Pakistan.

\section{Future Research Directions}

Further study is needed to explore more acceptability factors and to determine the acceptability of Islamic microfinance in all Islamic and non-Muslim nations. The research should focus on the poor and needy who require qard-e-hassan financing and other capacity-building opportunities to become active micro entrepreneurs. Small loan assessments are also available for the poor or target clientele, such as individuals who lack access to banks or financial institutions. 


\section{Reference}

Ahmad, H. (2007). "Waqf-based Microfinance: Realizing the social role of Islamic Finance", Paper written for the International Seminar on "Integrating Awqaf in the Islamic Financial Sector" Singapore, March 6-7,

Al-Ajmi, J., Hussain, H.A. and Al-Saleh, N. (2009). Clients of conventional and Islamic banks in Bahrain : How they choose which bank to patronize, International Journal of Social Economics, 36 (11), 1086-1112

Almossawi, M (2001) 'Bank selection criteria employed by college students in Bahrain: an empirical analysis', International Journal of Bank Marketing, 19:3, 115-25.

Amin, H., Abdul Rahman, A.R., Sondoh Jr, S.L., \& Chooi Hwa, A.M. (2011). Determinants of customers' intention to use Islamic Personal Financing, Journal of Islamic Accounting and Business Research, 2(1), 22-42.

Arebgeyen, O. (2011) .The Determinants of Bank Selection Choices by Customers: Recent and Extensive Evidence from Nigeria International, Journal of Business and Social Science Vol. 2, No. 22.

Ashrafi, H. (2017). Micro Credit as a Poverty Alleviation Tool in Turkey: A Case Study Analysis of Turkish Grameen Micro Credit Project. Asian Business Review, 7(1), 5-50.

Baber, H. (2019). E-SERVQUAL and Its Impact on the Performance of Islamic Banks in Malaysia from the Customer's Perspective. Journal of Asian Finance, Economics and Business, 6(1),.vol6.no1.169 169175.https://doi.org/10.13106/jafeb.2019

Bos, J. W., and M. Millone. 2015. Practice What You Preach: Microfinance Business Models and Operational efficiency. World Development 70

Brandsma, J., \& Burjorjee, D. (2004). Microfinance in the Arab States: Building inclusive financial sectors. United Nations Capital Development Fund, United States of America.

Butt, I., Ahmed, H., Altaf, M., Jaffer, K. and Mahmood, J. (2011). Barriers To Adoption Of Islamic Banking In Pakistan, Journal of Islamic Marketing,2(3), 259-273.

Burki, H.B and Chen, G. (2006). Microfinance Performance in Pakistan 1999-2005. Pakistan: USAID-funded WHAM (Widening Harmonized Access to Microfinance) Project, Pakistan Microfinance Network and Network and Shore Bank International Ltd.

Burns, N. and Grove, S.K. (1993). the practice of nursing research conduct, critique \& utilization (second edition), Philadelphia: W.B. Saunders.

Christen, R.P. (1998): Keys to financial sustainability: Strategic issues in microfinance .M.S

Kimenyi, R.C. Wieland and J.D.V. Pischke. Aldershot, England, Ahsgate.

Cicic M., Brkic N. and Agic E. (2004). Bank Selection Criteria Employed by Students in a Southeastern European Country: An Empirical Anal ysis of Potential Market Segments' Preferences; University of Sarajevo.

Comrey, A. L., \& Lee, H. B. (1992). A first course in factor analysis ( $2^{\text {nd }}$ ed.). Hillside, NJ: Erlbaum.

Dhumale R., Sapcanin A. (1999). “An Application of Islamic Banking Principles to Microfinance" Technical Note, A study bt yhe Regional Bureau for Arab States, UNDP, in cooperation with the Middle East and North Africa Region, World Bank.

El-Komi. M, Croson. R. (2012). Experiments in Islamic microfinance: Journal of Economic Behavior \& Organization, JEBO-2985; No. of Pages 18

Frasca, A. (2008). "A Further Niche Market: Islamic Microfinance in the Middle East and North Africa", Center for Middle Eastern Studies \& McCombs School of Business University of Texas, Austin.

Gait, A. and Worthington, A. (2008). An empirical survey of individual customer, business firms and financial institution attitudes towards Islamic methods of finance, International Journal of Social Economics, 35(11), 783-808.

Gait, A. and Worthington, A. (2009). Libyan Business Firm Attitude towards Islamic 
Methods of Finance. Social Science Research Network. [Online]. Available at http://ssrn.com/abstract $=1370752$.

Gefen, D. 2000. E-commerce: the role of familiarity and trust. Omega, 28, 725-737.

George, J. F. 2002. Influences on the intent to make Internet purchases. Internet Research, 12,165-180.

Gerrad, P. \& Cunningham, J. B. (2001) Islamic Banking: A Study in Singapore. International Journal of Banking Marketing, Volume 15 - 6, pp 204-216.

Gerrard, P., \& Cunningham, J.B. (2001). Singapore undergraduates: how they choose which bank to patronize. International Journal of Bank Marketing, 19 (3), 104-114.

Gholami, R., Ogun, A., Koh, E. and Lim, J. 2010. "Factors affecting e-payment adoption in Nigeria". Journal of Electronic Commerce in Organizations (JECO), 8, 51-67

Goud, B. (2007). "Islamic Microfinance" Institute of Halal Investing, U.S.A.

Gupta, D. (2014). "The impact of micro finance on rural households and its role in rural development and poverty alleviation-an analysis of north eastern villages of U.P India”, International Journal of Management (IJM), Vol. 5, pp.145-151.

Hamid, A. and Masood, O. (2011). "Selection criteria for Islamic home financing : A case study of Pakistan”, Qualitative Research in Financial Markets, 3 (2), 117-130.

Haque, A., Osman, \& Ismail, A. Z. (2009). "Factor Influences Selection of Islamic Banking: A Study on Malaysian Customer Preferences". American Journal of Applied Sciences, 6(5), 922-928.

Haron, S, Ahmad, N and Planisek, SL (1994) "Bank patronage factors of Muslim and nonMuslim customer", International Journal of Bank Marketing, 12:1, 32-40.

Hedayatnia, A., Eshghi, K. and Avenue, G. (2011). "Bank Selection Criteria in the Iranian Retail Banking Industry”, International Journal of Business and Management, 6 (12), 222-231.

Johnson, D. S. 2007. Achieving customer value from electronic channels through identity commitment, calculative commitment, and trust in technology. Journal of interactive marketing, 21, 2-22.

Kamal, N., J. Ahmed and A.K. Khalid (1999), "Islamic Banking: A study of customer satisfaction and preferences in Jordan." International Journal of Bank Marketing, 17: pp.135-150.

Kaburi. S. N, Ombasa.B.B \& Omato. D.N. (2011). " An overview of the role of Micro finance in radicating poverty in Kenya; A Lesson to be to be learnt from the emerging economics", International Journal of Arts and Commerce, ISSN 1929-7106.

Khan, M. A., \& Rahaman, M. A. (2007). "Impact of Microfinance on Living Standards, Empowerment and Poverty Alleviation of Poor People": A Case Study on Microfinance in the Chittagong District of Bangladesh. Master Thesis. Umeå School of Business (USBE), Sweden.

Khan, Muhammad, Akram. (1994). Rural development through Islamic Banks. Leicester: The Islamic Foundation.

Khavul, S. (2010). "Microfinance: Creating Opportunities for the Poor?", Academy of Management Perspectives.

Ledgerwood, J. (1999) Microfinance Handbook. Sustainable Banking with the Poor. An Institutional and Financial Perspective, the World Bank, Washington D.C.

Liu, T. C. and Wu, L. W. 2007. Customer retention and cross-buying in the banking industry: an Integration of service attributes satisfaction and trust. Journal of Financial Services Marketing, 12, 132-145.

Lewis, J. D. and Weigert, A. 1985. Trust as a social reality. Social forces, 63, 967-985.

Muhammad, H. (2020). Islamic Corporate Social Responsibility: An Exploratory Study in Islamic Microfinance Institutions. Journal of Asian Finance, Economics and Business, 7(12), 773-782. https://doi.org/10.13106/jafeb.2020.vol7.no12.773

Ngehnevu \& Nembo. ( 2010). The Impact of Micro Finance Institutions (MFIs) in the 
development of Small and Medium Size Businesses (SMEs) in Cameroon: A case study of CamCCUL.

Noipom. T (2014). Can Islamic Micro-financing Improve the Lives of the Clients: Evidence from a Non-Muslim Country: Kyoto Bulletin of Islamic Area Studies, 7 (March 2014), pp. 67-97.

Nunnally, J. C. (1978). Psychometric theory (2nd ed.). New York: McGraw-Hill.

Nunnally, J. C., and Bernstein, I. H. (1994). Psychometric theory. New York: McGraw Hill.

Otero, M. (1999) Bringing Development Back into Microinance. Journal of Microinance, Vol. 1, No. 1, 8-19.

Patel, S. (2004). “Takāful and Poverty Alleviation”, International Cooperative and Mutual I nsurance Corporation (ICMIF), London.

Pavlou, P. A. (2003). Consumer acceptance of electronic commerce: Integrating trust and risk with the technology acceptance model. International journal of electronic commerce, Vol. 7, 101-

Philip Gerard and Cunningham, J. B (1997) 'Islamic banking: A study in Singapore, International Journal of Bank Marketing, 15:6, 204-16.

Polit, D. and Hungler, B. 1997. Essentials of nursing research: methods, appraisal, and utilization (4th ed). J.B. Lippincott Company: Philadelphia, Pennsylvania, USA.

Rahman, M.M. (2010). "Islamic micro financing programme and Its Impact on rural poverty alleviation", International Journal of Banking and Finance, Vol. 7, pp. 119-138.

Robinson, M. 2001. The Microfinance Revolution; Sustainable Finance for the Poor. Vol.1 Washington. World Bank.

Rosenberg, Richard. (2002). Microcredit Interest Rates (Occasional Paper No.1). Washington: CGAP.

Roussea, D. M., Sitkin, S. B., Burt, R. S. and Camerer, C. 1998. Not so different after all: A cross-discipline view of trust. Academy of management review, 23, 393-404.

Saad, N.M. (2012). "Microfinance and Prospect for Islamic Microfinance Products: The Case of Amanah Ikhtiar Malaysia", Advances in Asian Social Science, Vol. 1, No. 1,

Schreiner, M. and Colombet, H.H. (2001) From Urban to Rural: Lessons for Microfinance from Argentina. Development Policy Review, Vol. 19, No.3, 339-354.

Segrado, C. (2005). "Case study; "Islamic microfinance and socially responsible investments".[Torino: University of Torino] Available at: $\quad<U R L$ : http://www.gdrc.org/icm/islamic-microfinance.pdf.

Sekaran, U. (2003), "Research method for business: A skill-building approach (4th Edition), New York, John Wiley \& Sons.

Sirdeshmukh, D., Singh, J. and Sabol, B. (2002). Consumer trust, value, and loyalty in relational exchanges. The Journal of Marketing, 15-37.

Smolo (2007) Micro-Crediting in Islam: Islamic Micro-financial Institutions,. Malaysia: International Islamic University.

Santandreu, E. M., Pascual, J. L., \& Rambaud, S. C. (2020). Determinants of repayment among male and female microcredit clients in the USA. An approach based on managers' perceptions. Sustainability (Switzerland), 12(5), 45-53. https:// doi.org/10.3390/su12051701

Suh, B. and Han, I. 2003. Effect of trust on customer acceptance of Internet banking. Electronic Commerce Research and Applications, 1, 247-263.

Shuttleworth, M., (2008). Quantitative Research Design. Retrieved from http://www.experimentresources.com/quantitative-research-design.html

Tara. N, Madiha. I \& Rizwan. M. "Factors Influencing Adoption of Islamic Banking: A Study from Pakistan", Journal of Public Administration and Governance, ISSN 2161-7104, 2014, Vol. 4, No. 3.

Wilson, R. (2007) Making Development Assistance Sustainable through Islamic finance. IIUM Journal of Economics and Management 15, No. 2: 197-217. 
Writz, J. and Matilla, A.S. (2003). The effects of consumer expertise on evoked set size and service loyalty. Journal of Service Marketing, 17 (7), 649-665.

Wright, G. (2000). Microfinance systems; designing quality financial services for the poor. New York: Zed Books Ltd.

Yap, K. B., Wong, D. H., Loh, C. and Bak, R. 2010. Offline and online banking-where to draw the line when building trust in e-banking? International Journal of Bank Marketing, $28,27-46$.

Yoon, S. J. 2002. The antecedents and consequences of trust in online-purchase decisions. Journal of interactive marketing, 16, 47-63.

Wright, G. A. N., Mutesasira, L. K., Okpara, G. C., Palmer, B., Walls, M., Burgess, Z., \& Hansen, N. (2019). Does microfinance reduce poverty? New evidence from Northeastern Mindanao, the Philippines. Small Enterprise Development, 12(1), 4661. https://doi.org/10.1016/j.jrurstud.2016.11.005

Yusoff. M.N.H. and Yaacob, M.R. (2010). The Government Business Support in the New Economic Model, International Journal of Business and Management, 5 (9), 60-71.

Zamore, S., et al. 2019. Geographic Diversification and Credit Risk in Microfinance.

Journal of Banking and Finance 109. 